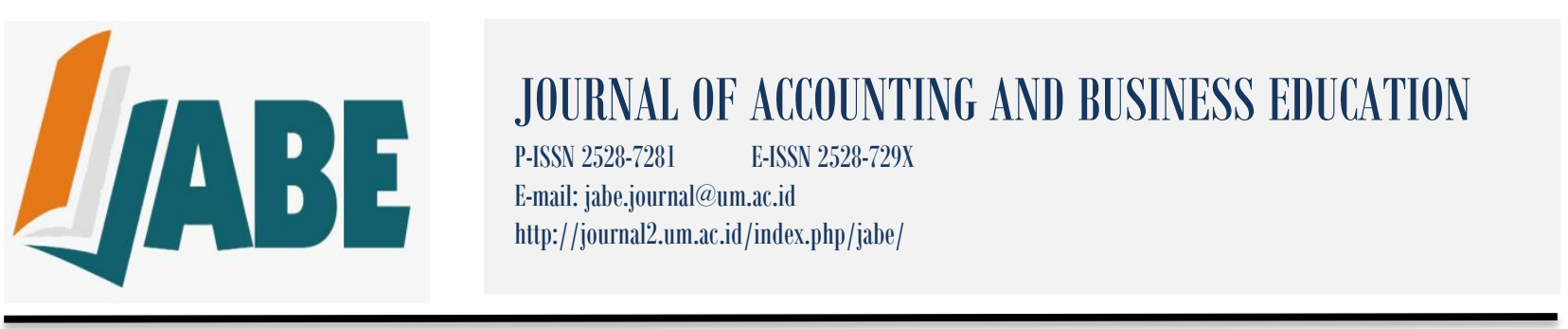

\title{
The Role of Financial Literacy on Financial Behavior
}

\author{
Pipit Rosita Andarsari ${ }^{1}$ \\ Mega Noerman Ningtyas ${ }^{2}$ \\ ${ }^{1,2}$ Accounting Department, STIE Asia Malang, Indonesia \\ email: meganoerman7@gmail.com
}

DOI: http://dx.doi.org/10.26675/jabe.v4i1.8524

\begin{abstract}
A number of previous empirical studies found that, financially speaking, literate people tends to do budgeting, saving, controlling expenses, managing debt well, participating in stock market and planning pension fund, etc. In other words, the higher an individual's knowledge and understanding of financial concept, the more likely they are to behave financially well in their daily life. Financial literacy is needed by everyone, including womenpreneur because not only they have to be able to manage their personal finance, they should also manage their business finance. Financially literate people are more likely to get access to external funding and to develop their business. This research aims to examine the role played by financial literacy on financial behavior of womenpreneur in Malang. Financial literacy was measured using 11 questions modified from Lusardi \& Mitchell (2011) and financial behavior was measured using 8 questions taken from INFE. The sample was 95 respondents who were female (owners of) Micro, Small and Medium Enterprises in Malang. The data were collected using questionnaire. We used Partial Least Square with Smart PLS 3 to examine the variables. After the first bootstrapping process, we drop some invalid indicators and then perform the second bootstrapping. The result showed that all of the remaining indicators were valid and financial literacy had been found to have positive significant (influence) on financial behavior.
\end{abstract}

Keywords: financial literacy, financial behavior, women entrepreneur, MSMEs.

\section{INTRODUCTION}

Woman is the future of the world's economy - in 2028, women will take $75 \%$ of the world's discretionary expenditure. Furthermore, the proportion of working women had increased by $23 \%$ in 1996 and $33 \%$ in 2013 . However, women received salary $18 \%$ less than men. This gap had troubled women, including in saving for their retirement. The statistics on savings, investment and loan level shows a fairly significant gender gap. If there is a program to help women deal with the challenges they face, they will certainly receive more salary and save more. An empowered woman will have positive impact on the economy and improve better standard of living (Bellet, 2018). The partnership between Indonesia and Australia in Investing in Women program shows that the contribution of UMKM to Indonesia's economy has reached 60\% towards Gross Domestic Product (GDP). This contribution cannot be separated from self-employed women whose number in 2018 has been 14.3 millions in which they contributed $9.1 \%$ to GDP PDB and 5\% to export. The number of manpower absorbed was 116.73 millions workers.

However, even with such a great contribution, MSMEs still had some obstacles in its way, including the access to financing in financial institutions (Lantu, Triady, Utami, \& Ghazali, 2016) where 
this could have been a determinant of MSMEs' success (Indarti \& Langenberg, 2004). The data show that the participation level of MSMEs in financial institutions is still low, i.e. only $30 \%$ of them can access financing. This limited access to capital from financial institutions has something to do with debtors' less or even not bankable profile, leading to their feasibility aspect being ignored (Suandi \& Susilo, 2011). This is because they find it hard to manage their money, particularly in recording their income and expenditure. Meanwhile, the financial institution need financial statements which reflect the actual condition of MSMEs for providing their services (Siregar \& Veronica, 2012).

In SNLKI OJK (2016) publication, the financial literacy level in Indonesia is still at $29.7 \%$. This means they have no understanding nor trust in financial institution's services, financial products and services and have no skills in using these financial products and services. Empirical studies find that financial literacy has positive impact on an individual's financial behavior and financial status. Literate individual will be able to do well in such things as: budgeting, saving, controling spending (Moore, 2003; Perry and Morris, 2005); managing debts (Campbell, 2006; Brown \& Graf, 2013), Lusardi and Tufano, 2015); managing household finance (Bellet, 2018); participating in capital market (Van Rooij, Lusardi et al., 2011; Christelis, Jappelli et al., 2010; Yoong, 2010; Baker, et., 2019); purchasing high-risk investment assets (Bannier \& Neubert, 2016; Bianchi, 2017); planning retirement (Kumar, Tomar, \& Verma, 2019; Lusardi \& Mitchell, 2007, 2008); and most importantly successfully accumulating wealth (Stango and Zinman, 2009; Bellet, 2018). From the perspective of business, the more literate an individual the more likely for them to access external funding and develop their businesses (Hussain, Salia, \& Karim, 2018). In other words, the greater an individual's financial knowledge the wiser their financial behavior would be.

It is important for MSME owners to have a good financial behavior since in addition to having to be careful in managing their personal finance, they have to manage their business finace as well. Many MSME owners think their sales increases, yet the profit they receive remains the same. Also, many MSME owners mix their personal and business finances. Some of them even have no adequate financial recording. Widayanti et al., (2017) suggest this is due to the low interests of MSME owners to record and book each of the transactions they make and this will eventually make it difficult for them to monitor how their businesses are doing. In addition, the financial institution will also find it hard to minimize the default risk for the loan given to MSMEs. In Dahmen \& Rodriguez's (2014) research, out of 14 MSMEs which is poorly-managed finance, there are 7 experience financial difficulties, 4 of which are owned by women.

Several financial issues found in MSMEs are interesting for further studies UMKM to give some contribution in solving the problems encountered by MSME owners in which most of them are not bound by financial planning, budgeting and financial control (Fatoki, 2014). This includes womanpreneurs who also contribute to the state's economy substantially. They need to be empowered optimall by enriching their knowledge on finance. It is expected that doing so will allow them to improve their financial behavior. This is the starting point of the researcher's purpose to investigate the role played by financial literacy on financial behavior in woman entrepreneurs in Malang Municipality.

\section{LITERATURE REVIEW AND HYPOTHESES}

Mendes-da-silva (2016) in his research states that the term financial literacy has frequently been used as a synonym for financial education or financial knowledge. However, this construct is actually conceptually different since financial literacy has deeper meaning than financial education. Thus, using the two terms interchangeably to mean the same meaning might lead to misunderstanding. Financial literacy has two dimensions, namely understanding which represents personal financial knowledge from financial education and use which refers to management of personal financial knowledge. In this context, an individual might have financial knowledge, yet for them to be considered literate, they have to own the ability and self-confidence to implement decisions. Therefore, financial literacy is more complex than merely the basic concept of financial education. 
In reference to OJK, there are four levels of financial literacy classification, namely: 1) well literate-more than $80 \%$, having understanding and trust on financial service institution and financial products and services, including financial products and services-related features, benefits and risks, and rights and duties, as well as having the skills in using financial products and services; 2) sufficient literate $-60-80 \%$, having understanding and trust on financial service institution and financial products and services, including financial products and services-related features, benefits and risks, and rights and duties; 3) less literate-30\%-60\%, only having understanding on financial service institution, financial products and services; dan 4) not literate-less than 30\%, having neither understanding nor trust on financial service institution and financial products and services, and having no skills in using financial products and services.

This study uses financial literacy index based on DEFINIT-SEADI-OJK (2013) where they refer to Lusardi and Mitchell's (2011) research. There are two 2 indicators, namely basic financial literacy and advanced financial literacy. However, to match the research subjects who mostly do not really understand capital market, the indicator used is only basic financial literacy. This basic financial literacy consists of 11 questions which include: 1) Identity when opening an account; 2) Minimum fund deposit when opening an account; 3) Minimum balance in account; 4) Guarantee of savings; 5) Simple interest; 6) Compound interest; 7) Interest on loan; 8) Discount; 9) Inflation; 10) Temporary value of money; 11) Money illusion. This study uses dummy variable ( 1 and 0$)$ if the respondent's answer is correct then they will be assigned with code 1 and 0 if it is wrong.

Financial behavior is associated with one's responsibility regarding their way of managing money. An effective financial management includes budgeting, assessing the importance of purchase and prioritizing needs and so on. The budgeting process is done to ensure that individuals can manage their financial obligations punctually using the income they receive (Ida \& Dwinta, 2010). This financial behavior variable is measured using 8 question items modified from OECD-INFE (International Network on Financial Education), namely: 1) Cautious in purchasing goods; 2) Focus in using money; 3) Saving; 4) Paying bills punctually; 5) Ready to take risk of an investment; 6) Making budget; 7) Making longterm financial plan; 8) Controlling spending. The measurement scale uses Likert scale, from "never" (score 1) to "always" (score 5).

The empirical evidence shows that financial literacy has a positive impact on financial behavior. Individuals with knowledge and ability in managing their finances well will shows a good financial behavior such as investing, saving, and using credit card. An empirical study by Lusardi \& Tufano (2015) shows that people with low financial literacy are more likely to have problems with money. Without adequate knowledge, entrepreneurs or MSMEs are more likely to be trapped in debts at high interests. Furthermore, they will also be spared from informal lenders or loan sharks (Oktavianti, Hakim, \& Kunaifi, 2017).

H1 : Financial literacy has a positive influence on financial behavior.

\section{METHODS}

The data in this research are collected using direct survey method with questionnaire instrument to the research respondents, i.e. womenpreneurs in Malang Municipality. The sample is taken using purposive sampling technique, i.e. sampling based on a certain purpose. The criteria set by the research are 1) Offering more than one types of products or services; 2) Operating or having office in the research area; 3) Respondents are the owners or managers who are person in charge for that business.

The minimum number of sample determined by Heir (1995) is the number of indicators multiplied by five, thus the minimum number of respondents required is 95 respondents. The respondents were collected by attending entrepreneurship seminars organizaed by entrepreneur communities in di Malang such as MCF (Malang Creative Fusion) and RPMR (Rumah Pengusaha Malang Raya). The researcher needs enumerator's help to collect the data. For hard-to-access MSMEs, the researcher would contact via 
telephone or give the quistionnaire online. The collected data are then processed using SmartPLS 3 to test the proposed hypotheses.

The research instruments used also need to be tested for their validity and reliability. The validity test is performed to test whether the question items asked could measure accurately what is about to be measured and reliability test is used to measure the consistency of indicators of variables (Ghozali, 2007). The measurement model or outer model with reflexif or formative indicators is analyzed by seeing the convergent validity of each indicator. Any indicator with loading factor less than 0.50 will be discarded. The reliability of research constructs is assessed by seeing the value of its composite reliability and cronbach alpha. It is said to have a good reliability if the minimum value is 0.60 .

Inner model captures the association between latent variables based on substantive theory. Inner model is evaluated by seeing the variance percentage being explained as indicated by the value of $\mathrm{R}^{2}$. For dependent latent constructs, the measurement uses Stone-Geisser Q Square Test by seeing the amount of its structural path coefficient. The estimation stability is evaluated using statistic t-test which is obtained through bootstrapping procedure.

\section{RESULTS}

\section{Respondent Profile}

This research is addressed to MSME owners in Malang. Of a total of 95 female MSME owners from whom the data were collected, most of them run their businesses in food and beverage field. It is followed by those running their businesses in fashion. In terms of how long they have been operating, $42 \%$ womenpreneurs have run their businesses for 1-3 years. Among these respondents, a fairly great number at $20 \%$ just begin to run their businesses (startup). And from the perspective of financial behavior, they score 3.76 (good) on average.

Table 1. Descriptive analysis

\begin{tabular}{cc}
\hline Business Line: & Percentage \\
\hline Fashion & $30.28 \%$ \\
Food and Beverage & $47.71 \%$ \\
Crafts & $21.10 \%$ \\
Beauty & $0.92 \%$ \\
Business Age: & \\
Startup & $20.18 \%$ \\
$\mathbf{1 - 3}$ years & $42.20 \%$ \\
$\mathbf{4 - 5}$ years & $21.10 \%$ \\
>5 years & $16.51 \%$ \\
Business size: & \\
Micro Business & $91.74 \%$ \\
Small Business & $0.92 \%$ \\
Medium Business & $1.83 \%$ \\
Total N & 95 \\
\hline Financial Literacy Mean & $67,56 \%$ \\
& Sufficient literate \\
\hline Financial Behavior Mean & 3,76 \\
& baik \\
\hline
\end{tabular}

The mean financial literacy index of womenpreneurs in Malang is shown in detail in the table below. The mean value of financial literacy index of these womenpreneurs is $67.56 \%$ or classified as sufficient literate. This means they have the understanding and trust on financial service institution as well as 
financial products and services, including the features, benefits and risk, and rights and duties related to financial products and services (OJK, 2014). They are said to be sufficiently literate since they have had the understanding and knowledge on finance yet lack the skills in using financial products and services.

Table 2. Descriptive Analysis of Financial Literacy

\begin{tabular}{ccc}
\hline Code & Financial Literacy Category & $\%$ \\
\hline $\mathbf{1}$ & not literate & $3.67 \%$ \\
$\mathbf{2}$ & less literate & $22.94 \%$ \\
$\mathbf{4}$ & sufficient literate & $42.20 \%$ \\
\hline
\end{tabular}

A person's financial literacy level is distinguished into four as shown in table 2 above. The well literate category in these respondents reaches to $31 \%$ of the total. In this stage, an individual has knowledge and trust on financial service institution and financial products and services, including their features, benefits and risks, and rights and duties related to financial products and services, and they have the skills in using financial products and services. Most respondents belong to sufficient literate category, in which an individual has knowledge and trust on financial service institution and financial products and services, including their features, benefits and risks, and rights and duties related to financial products and services. In less literate category, the percentage is over $23 \%$ where respondents only have knowledge on financial service institution, financial products and services. The last categoty, not literate, means an individual has neither knowledge nor trust on financial service institution and financial products and services, and has no skills in using financial products and services.

Table 3. Percentage of Each Financial Literacy Indicator

\begin{tabular}{clc}
\hline No. & \multicolumn{1}{c}{ Indicator } & \% correct answers \\
\hline $\mathbf{1}$ & Identity when opening an account & $100.00 \%$ \\
$\mathbf{2}$ & Minimum fund deposit when opening an account & $95.41 \%$ \\
$\mathbf{3}$ & Minimum balance in account & $91.74 \%$ \\
$\mathbf{4}$ & Guarantee of savings & $55.05 \%$ \\
$\mathbf{5}$ & Simple interest & $62.39 \%$ \\
$\mathbf{6}$ & Compound interest & $25.69 \%$ \\
$\mathbf{7}$ & Interest on loan & $57.80 \%$ \\
$\mathbf{8}$ & Discount & $89.91 \%$ \\
$\mathbf{9}$ & Inflation & $49.54 \%$ \\
$\mathbf{1 0}$ & Temporary value of money & $42.20 \%$ \\
$\mathbf{1 1}$ & Money illusion & $53.21 \%$ \\
\hline
\end{tabular}

In latent variables of Financial Literacy, there are 11 indicators or constructs which represent how a person can be said as having knowledge and understanding financial concept. The first question is basic knowledge related to banking. "Do you need an ID card when you open an account in a bank?" All respondents answered this question correctly. Most respondents answer incorrectly and say they have no idea when the sixth question was asked, i.e. in relation to compound interest. Suppose you have a saving worth Rp1,000,000 with an interest $4 \%$ per year. (Assuming you do not pay administrative fee and you neither deposit nor withdraw money from your account), after two years, how much will you own in your account (including interest)? Knowledge on interest (both simple and compound interests) is highly important to help the individual estimate the savings they will have in the future and helped them made profitable loan decision for themselves. 


\section{Evaluation of Model Goodness of Fit}

Based on the research purpose and specification, a test is conducted in stages (iteration) using SmartPLS 3, to obtain a fit test result. The result of conceptual model goodness of fit evaluation in Figure 1 shows that the values of loading factors of some indicators are still below $<0.5$ which mean they have to be dropped from the research model, namely FL1, FL4, FL6, FB2 and FB8. Knowledge on Identity When opening an account, Guarantee of savings dan Compound interest fail to execute its measuring function appropriately or, in other words, fail to represent the latent variable of Financial literacy. The Focusing on Money Use Management and Controlling Money and Controlling Spending indicators in Financial Behavior fail to explain well in the latent variable.

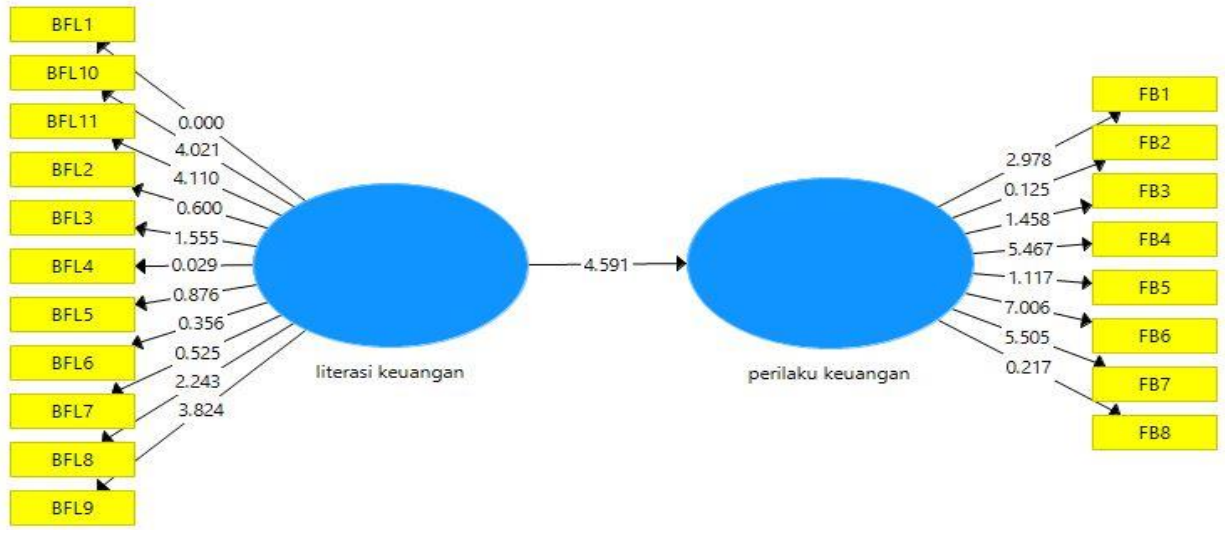

Figure 1. Output of SmartPLS 3 Model Analysis

Below is the result of model evaluation made after dropping several invalid indicators. The test result in Table 4 shows that all outer loadings of construct indicators have loading values $>0.5$; thus it can be concluded that this measurement successfully meets the convergent validity. The discriminant validity result shows that the value of root square of average variance extracted (AVE) is greater than 0.5. The reliability test result indicates a reliable result since the value of composite reliability (rc) was above 0.6. Likewise, the value of cronbach alpha of both variables is over 0.6. For inner model Q-Square, it shows greater number than 0 , thus it can be said that the model is feasible for estimation.

Table 4. Evaluation of Structural Model Goodness of Fit Index Criteria

\begin{tabular}{|c|c|c|c|c|}
\hline \multirow[t]{2}{*}{ Criteria } & \multicolumn{2}{|c|}{ Result } & Critical & Model Evaluation \\
\hline & \multicolumn{3}{|c|}{ Outer Model } & \\
\hline \multirow[t]{12}{*}{ Convergent Validity } & Indicator & Construct & $\geq 0.5$ & \\
\hline & FL3 & 2.379 & & \multirow[t]{11}{*}{ valid } \\
\hline & FL5 & 0.946 & & \\
\hline & FL7 & 0.678 & & \\
\hline & FL8 & 2.241 & & \\
\hline & FL9 & 6.190 & & \\
\hline & FL10 & 4.433 & & \\
\hline & FL11 & 5.580 & & \\
\hline & FB1 & 2.991 & & \\
\hline & FB3 & 1.791 & & \\
\hline & FB4 & 8.379 & & \\
\hline & FB5 & 1.305 & & \\
\hline
\end{tabular}




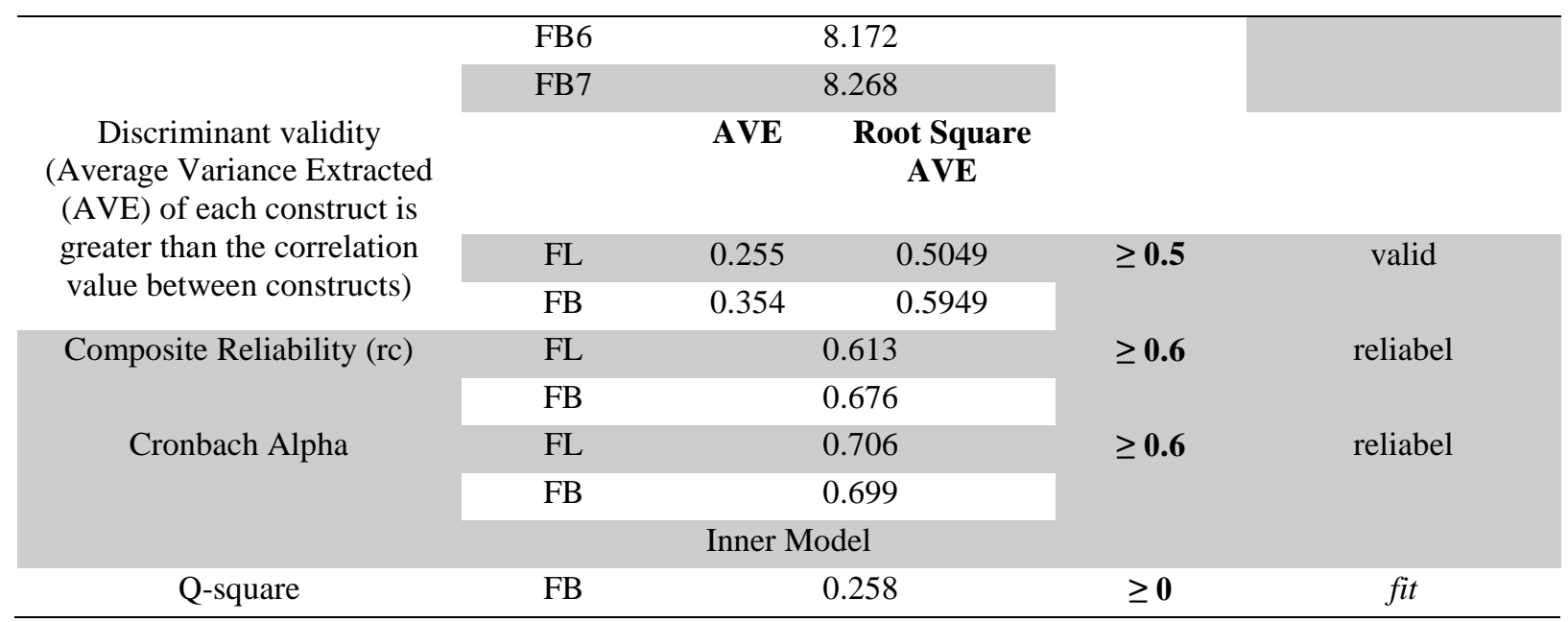

The next step after model feasibility test is test of influence between latent variables. The test result shows that the $\mathrm{t}$ statistic value is 9.290 (See appendix) in which this influence is significant at $1 \%$ level ( $\mathrm{t}$ statistic $9.290>\mathrm{t}$ table 1.984). It can therefore be concluded that the better people understand financial concept, the better they would in managing their finance.

\section{DISCUSSION}

The research result indicate that financial literacy has an influence on financial behavior. In fact, an individual's financial literacy plays an important role in shaping wealth equity. Having good financial knowledge helps women to make wise decisions, saving more for retirement, manage investment carefully, and manage household finance better. On the other hand, less literate persons rarely make efficient choices and are more likely to cause more debts, save less and are more prone to fraud. Thus, it is important to figure out to what extent women's understanding on basic financial concepts and to what extent their financial skills fail. In some other studies, it is found that financial literacy in women tends to be lower than in men (Falahi \& Paim, 2011; Atkinson \& Messi, 2012; Bottazzi \& Lusardi, 2016; Hasler, 2017; Moon et al., 2014).

This difference is hard to explain since no single satisfactory explanation can deal with the difference in financial literacy level between women and men (Bucher-koenen et al., 2011). Likewise, demographic difference also fails to explain well this gender gap (Fonseca \& et al., 2010). The result of statistic description processing above indicates that on average the financial literacy level in womenpreneur respondents is in 'adequately literate' category. This means the respondents have knowledge and trust on financial service institutions and financial products and services, including features, benefits and risks, rights and duties related to financial products and services. However, they are less capable of and less skillful in utilizing these financial products and services.

Referring to the definition of financial literacy from Lusardi \& Mitchell (2011a), financial literacy is definied not limited to merely knowledge, rather it involves self-confidence to do something. They find that women score lower than men when the option "I don't know" is among the available choices. Nevertheless, when this "I don't know" option is removed, women score equally to men. This is consistent with Asaad (2015) who states that financial confidence is a critical component in financial literacy. His research result indicates that individuals with high knowledge and self-confidence are more likely to make good financial decisions than those with low knowledge and self-confidence. However, overconfidence is not good either since they are more likely to overestimate their own knowledge accuracy and underestimate the risk they face. Hence, even without even realizing it, overconfident individuals are more likely to be involved in risky financial behavior such as, among other things, borrowing money at high interest rate.

Understanding that self-confidence is equally important with knowledge, it is important for educational institutions and policymakers to prepare a more effective financial literacy initiative to 
improve daily financial decision making. The challenge then is to create an educational initiative which helps individuals find the right (no less and no more) self-confidence dose.

The result of the hypothesis testing made is consistent with the research conducted by Ida \& Dwinta (2010), Robb \& Woodyard (2011), Scheresberg (2013), Siahaan (2013), Brown \& Graf (2013), Asaad (2015), Grohmann, Kouwenberg, \& Menkhoff (2015), Hamdani (2018). Whether a financial behavior is wise or not is tightly related to a person's knowledge on financial concepts. When this person knows and understand, then he/she will use the knowledge he/she has as the basis for making decision of the action he/she is about to take.

One of the aspects in financial literacy is inflation-related knowledge. For example in inflation aspect, when a person knows and understands that the value of money gets lower and lower as time goes, then he/she will choose and decide the type of investment with a return abovethe inflation rate at that year. Knowledge on inflation will also prevent a person from practicing more consumptive behavior. $\mathrm{He} / \mathrm{she}$ will think that the money he/she owns is not to be spent only for today.

The same applies to a person who wish to start a business. They are demanded to not just be capable of managing their personal finance, rather they need to manage their business finance as well. This is where financial knowledge plays its role for entrepreneurs to allow them to develop their business without having to deal with financial issues. Another equally important aspect in financial literacy is knowledge on interest rate. In this aspect, if entrepeneurs decide to take a loan, when they understand well the interest concept then they are more likely to choose the loan with relatively low interest. This is in line with Lusardi \& Tufano (2015) who suggest that non-literate person will more likely to take a debt at high interest rate.

Another benefit of financial literacy for entrepreneurs is it increase financing access at financial institution where in Indonesia's case the participation is fairly low, i.e. only $30 \%$ can access the financing. This limited access to financial institutions has something to do with the debtor's less or even not bankable profile, making the feasibility aspect neglected (Suandi \& Susilo, 2011). the financial institution need financial statements which reflect the actual condition for providing their services. Yet, making these financial statements is something hard for them to do due to the lack of knowledge of financial management which includes financial recording (Siregar \& Veronica, 2012).

Furthermore, an individual's behavior is not merely based on what they understand or know, rather it still has something to do with their self-confidence. Knowledge drives a person's self-confidence to do something (Ramalho \& Forte, 2019). A good financial behavior is the basic need for all people and entrepeneurs are not an exception. Most people tend to learn their personal financial management as they grow older and through trial and error process, leading them to a difficult situation when they have been trapped in a poor financial behavior.

Some previous studies (Xiao et al., 2008; Mandell \& Klein, 2009; Xiao \& Porto, 2017) conclude that the best way of fixing behavior at older age is by teaching a good financial education since childhood. Knowledge on financial literacy ought to be given as early as possible to allow them to apply it better in their daily life (Hamdani, 2018). Financial education at schools could take youth's financial ability forward. Unfortunately, in Indonesia personal finance education is still rarely found, be it at universities let alone elementary schools. Making personal financial education a compulsory course at universities will equip the youth with the necessary skills and knowledge to develop in today's increasingly complex financial environment.

\section{CONCLUSION}

The research result indicates that womenpreneurs in Malang Municipality has 'good enough' financial literacy. The result of test of influence also indicates that financial literacy has a positive influence on financial behavior. The higher a person's financial knowledge, the better and wiser their financial behavior would be. Financial knowledge or literacy is needed as the basis for making decisions in daily life, regardless whether or not they run a business. The limitation of this research is that its subjects cover only womenpreneurs in Malang Municipality. The recommendation for further research is, 
among other things, to widen the scope of sample (not limited only to Malang Municipality), modify the model into a more complex one, widen the measuring indicator coverage and deepen the tools for analysis to be used (possibly using SEM).

\section{REFERENCES}

Anstey, C. (2012). Women in the Private Sector: Good for Development and Business. In Remarks by World Bank Managing Director at the 2012 Annual Meetings Program of Seminars, Tokyo Japan.

Asaad, C. T. (2015). Financial literacy and financial behavior: Assessing knowledge and confidence, 24, $101-117$.

Baker, H. K., KUmar, S., Goyal, N., \& Gaur, V. (2019). How financial literacy and demographic variables relate to behavioral biases. Managerial Finance, 45(1), 121-146. https://doi.org/10.1108/MF-01-2018-0003

Bannier, C. E., \& Neubert, M. (2016). Gender differences in financial risk taking: The role of financial literacy and risk tolerance. Economics Letters, 145, 130-135. https://doi.org/10.1016/j.econlet.2016.05.033

Bellet, E. (2018). Empowering Women Financially - The Why and the How. In The Fintech Handbook for Investors, Entrepreneurs and Finance Visionaries (Vol. 194, pp. 194-196).

Bianchi, M. (2017). “Financial Literacy and Portfolio Dynamics .” Working Papers, (May).

Bottazzi, L., \& Lusardi, A. (2016). Gender Differences in Financial Literacy: Evidence from PISA, (February).

Brown, M., \& Graf, R. (2013). F Inancial Literacy, H Ousehold I Nvestment And H Ousehold D Ebt : E Vidence From S Witzerland. Working Papers on Finance, 13(1).

Bucher-koenen, T., Lusardi, A., Börsch-supan, A., Fornero, E., Gasche, M., Haliassos, M., ... Lefter, A. (2011). Financial Literacy and Retirement Planning in Germany. Journal of Pen, 10(4), 565-584.

Dahmen, P., \& Rodríguez, E. (2014). Financial literacy and the success of small businesses: An observation from a small business development center. Numeracy, 7(1), 3.

Falahi, L., \& Paim, L. (2011). Gender Differences in Financial Literacy among College Students. Journal of American Science, 7(6).

Fatoki, O. (2014). The Causes of the Failure of New Small and Medium Enterprises in South Africa. $\begin{array}{llll}\text { Mediterranean Journal of Social } & \text { Sciences, } & \text { 522-927, }\end{array}$ https://doi.org/10.5901/mjss.2014.v5n20p922

Fonseca, R., \& et al. (2010). What Explains the Gender Gap in Financial Literacy? Working Papers, June.

Grohmann, A., Kouwenberg, R., \& Menkhoff, L. (2015). Childhood roots of financial literacy. Journal of Economic Psychology, 51, 114-133. https://doi.org/10.1016/j.joep.2015.09.002

Hamdani, M. (2018). Analisis tingkat literasi keuangan dan pengaruhnya terhadap perilaku keuangan pada mahasiswa prodi manajemen universitas terbuka. Jurnal Bakti Masyarakat Indonesia, 1(1), $139-145$.

Hasler, A. (2017). The Gender Gap in Financial Literacy : A Global Perspective.

Hussain, J., Salia, S., \& Karim, A. (2018). Is knowledge that powerful? Financial literacy and access to finance An analysis of enterprises in the UK. Financial Literacy and Access to Finance, 25(6), 9851003. https://doi.org/10.1108/JSBED-01-2018-0021

Ida, \& Dwinta, C. Y. (2010). Pengaruh Locus of Control, Financial Knowledge, Income Terhadap Financial Management Behavior. Jurnal Bisnis Dan Akuntansi, 12(3), 131-144.

Kumar, S., Tomar, S., \& Verma, D. (2019). Women' s financial planning for retirement Systematic literature review and future research agenda. International Journal of Bank Marketing, 37(1), 120141. https://doi.org/10.1108/IJBM-08-2017-0165

Lantu, D. C., Triady, M. S., Utami, A. F., \& Ghazali, A. (2016). Pengembangan Model Peningkatan Daya Saing UMKM di Indonesia: Validasi Kuantitatif Model. Jurnal Manajemen Teknologi, 15(1), 77- 
93. https://doi.org/10.12695/jmt.2016.15.1.6

Lusardi, A., \& Mitchell, O. S. (2007). Baby Boomer retirement security: The roles of planning, financial literacy, and housing wealth. Journal of Monetary Economics, 54(1), 205-224. https://doi.org/10.1016/j.jmoneco.2006.12.001

Lusardi, A., \& Mitchell, O. S. (2008). Planning And Financial Literacy: How Do Women Fare? National Bureau of Economic Research.

Lusardi, A., \& Mitchell, O. S. (2011). Financial Literacy Around The World: National Bureau of Economic Research.

Lusardi, A., \& Tufano, P. (2015). Debt Literacy, Financial Experiences, And Overindebtedness. Journal of Pension Economics \& Finance, 14(4), 332-368.

Mandell, L., \& Klein, L. S. (2009). The Impact of Financial Literacy Education on Subsequent Financial Behavior, (206), 15-24.

Mendes-da-silva, W. (2016). Development of a financial literacy model for university students. Management Research Review, 39(3), 356-376. https://doi.org/10.1108/MRR-06-2014-0143

Moon, C., Korea, S., Ohk, K., Korea, S., Choi, C., \& Korea, S. (2014). Gender Differences in Financial Literacy among Chinese University Students and the Influential Factors*. Asian Women, 30(2).

Oktavianti, V., Hakim, M. ., \& Kunaifi, A. (2017). Pengaruh Literasi Keuangan dan Persyaratan Kredit terhadap Akses Kredit Formal pada UMKM di Surabaya. Jurnal Sains Dan Seni Its, 6(2017), 1-5.

Ramalho, T. B., \& Forte, D. (2019). Financial literacy in Brazil - do knowledge and self-con fi dence relate with behavior? RAUSP Management Journal, 54(1), 77-95. https://doi.org/10.1108/RAUSP04-2018-0008

Robb, C. A., \& Woodyard, A. S. (2011). Financial Knowledge and Best Practice Behavior, (205), 60-70.

Scheresberg, C. D. B. (2013). Financial literacy and financial behavior among young adults: Evidence and implications. Numeracy, 6(2), 1-21. https://doi.org/http://dx.doi.org/10.5038/1936-4660.6.2.5

Siregar, R., \& Veronica, S. (2012). Jurnal Akuntansi dan Keuangan Indonesia. Jurnal Akuntansi Dan Keuangan Indonesia, 9(1), 1-21.

Suandi, E., \& Susilo, Y. S. (2011). Strategi Pengembangan Usaha Mikro Kecil Dan Menengah Di Provinsi Daerah Istimewa Yogyakarta *, 12, 45-55.

Widayanti et al. (2017). Pengaruh FInancial Literacy terhadap Keberlangsungan Usaha pada UMKM. Jurnal Ilmiah Manajemen \& Bisnis, 18(2), 153-162.

Xiao, J. J., \& Porto, N. (2017). Financial education and financial satisfaction. International Journal of Bank Marketing, 35(5), 805-817. https://doi.org/10.1108/IJBM-01-2016-0009

Xiao, J. J., Ahn, S. Y., Serido, J., \& Shim, S. (2014). Earlier Financial Literacy and Later Financial Behaviour of College Students. International Journal of Consumer Studies, 38(6), 593 - 601.

Yoong, J. (2011). Financial illiteracy and stock market participation: Evidence from the RAND American Life Panel. Financial literacy: Implications for retirement security and the financial marketplace, 76. 